\title{
Distribution of soil nitrogen and nitrogenase activity in the forefield of a High Arctic receding glacier
}

\author{
Thomas TURPIN-JELFS, ${ }^{1}$ Katerina MICHAELIDES, ${ }^{1,2}$ Joshua J. BLACKER, ${ }^{3}$ \\ Liane G. BENNING, ${ }^{3,4,5}$ James M. WILLIAMS, ${ }^{1}$ Alexandre M. ANESIO ${ }^{1,6}$ \\ ${ }^{1}$ School of Geographical Sciences, University of Bristol, Bristol, BS8 1SS, UK. \\ E-mail: thomas.turpin-jelfs@bristol.ac.uk \\ ${ }^{2}$ Earth Research Institute, University of California Santa Barbara, Santa Barbara, CA, USA \\ ${ }^{3}$ School of Earth and Environment, University of Leeds, Leeds, LS2 9JT, UK \\ ${ }^{4}$ GFZ, German Research Centre for Geosciences, 14473, Potsdam, Germany \\ ${ }^{5}$ Department of Earth Sciences, Free University of Berlin, 12249, Berlin, Germany \\ ${ }^{6}$ Department of Environmental Science, Aarhus University, 4000 Roskilde, Denmark
}

\begin{abstract}
Glaciers retreating in response to climate warming are progressively exposing primary mineral substrates to surface conditions. As primary production is constrained by nitrogen $(\mathrm{N})$ availability in these emerging ecosystems, improving our understanding of how $\mathrm{N}$ accumulates with soil formation is of critical concern. In this study, we quantified how the distribution and speciation of $\mathrm{N}$, as well as rates of free-living biological $\mathrm{N}$ fixation (BNF), change along a 2000-year chronosequence of soil development in a High Arctic glacier forefield. Our results show the soil $\mathrm{N}$ pool increases with time since exposure and that the rate at which it accumulates is influenced by soil texture. Further, all $\mathrm{N}$ increases were organically bound in soils which had been ice-free for $\mathbf{0 - 5 0}$ years. This is indicative of $\mathrm{N}$ limitation and should promote BNF. Using the acetylene reduction assay technique, we demonstrated that microbially mediated inputs of $\mathrm{N}$ only occurred in soils which had been ice-free for 0 and 3 years, and that potential rates of BNF declined with increased $N$ availability. Thus, BNF only supports $N$ accumulation in young soils. When considering that glacier forefields are projected to become more expansive, this study has implications for understanding how ice-free ecosystems will become productive over time.
\end{abstract}

KEYWORDS: Arctic glaciology, biogeochemistry, microbiology, moraine

\section{INTRODUCTION}

Since $\sim 1850$, glacier coverage in high latitude and altitude regions has continued to decline in response to climate warming (Stocker and others, 2013). Retreating glaciers progressively expose soil-forming mineral substrates to surface conditions and biotic colonisation (Breen and Lévesque, 2008). Thus, glacier forefields are comprised from linear arrays of soil development stages which provide unique opportunities to investigate long-term primary succession and ecosystem development (Bradley and others, 2014). As terrestrial primary production and ecosystem functioning are typically limited by the availability of nitrogen $(\mathrm{N}$; Vitousek and others, 1997), advancing our understanding of how $\mathrm{N}$ accumulates with soil formation is crucial to identifying the long-term productivity of these ecosystems (Bradley and others, 2014).

The development of soils at high latitudes occurs over relatively long timescales as soil forming processes are highly constrained by low temperatures, short growing seasons and slow weathering rates (Ellis and Mellor, 1995). Using space-for-time substitutions, where distance from the leading edge of a retreating glacier serves as a proxy for soil age (post-incisive chronosequence), it has been shown that soil $\mathrm{N}$ typically increases with time since glacial retreat (Bradley and others, 2014). Principal inputs which contribute to the accumulation of $\mathrm{N}$ in these ecosystems include biological $\mathrm{N}$ fixation (BNF) by free-living (asymbiotic) soil bacteria and plant-microbe associations, mineralisation of organic matter previously overridden by the ice, and allochthonous loadings from aerial deposition and glacial runoff (Brankatschk and others, 2011). While the relative contributions of these inputs may vary, asymbiotic BNF is widely considered to be the dominant source of assimilatory $\mathrm{N}$ during the initial stages of soil development (Bradley and others, 2014).

As primary mineral substrates generally lack $N$ (Vitousek and Farrington, 1997), the initial colonisation of recently deglaciated soils is largely restricted to asymbiotic microorganisms with the capacity to convert atmospheric dinitrogen $\left(\mathrm{N}_{2}\right)$ into $\mathrm{N}$-containing organic compounds (diazotrophs; Duc and others, 2009). This process is mediated by the nitrogenase enzyme which catalases the adenosine triphosphatedependent reduction of $\mathrm{N}_{2}$ to ammonia (Vitousek and others, 2002). Due to a high phosphorus ( $P$ ) demand for adenosine triphosphate, it is expected that BNF will down-regulate as the availability of soil $\mathrm{N}$ increases relative to bioavailable P (Menge and Hedin, 2009). However, the factors influencing the extent and distribution of BNF in glacier forefield ecosystems are poorly resolved (Brankatschk and others, 2011).

Inputs of $\mathrm{N}$ by asymbiotic BNF to forefield systems facilitate subsequent colonisation by heterotrophic microorganisms capable of mineralising soil organic matter (Bradley and others, 2014). As soil organic matter typically contains $>90 \%$ of all soil $\mathrm{N}$, mineralisation represents a major process controlling the availability of $\mathrm{N}$ in many terrestrial 
ecosystems. Inorganic $\mathrm{N}$, which is defined hereinafter as the sum of ammonium $\left(\mathrm{NH}_{4}-\mathrm{N}\right)$ and nitrate $\left(\mathrm{NO}_{3}-\mathrm{N}\right)$, is either liberated or immobilised by the heterotrophic community during mineralisation when $\mathrm{N}$ is in excess or limiting, respectively (Hassink, 1994). Thus, the availability of inorganic $\mathrm{N}$ is strongly influenced by the stoichiometry between soil organic carbon (SOC) and total N (DelgadoBaquerizo and others, 2015). While previous studies have quantified inorganic $\mathrm{N}$ availability in forefield soils (e.g., Duc and others, 2009; Töwe and others, 2010; Knelman and others, 2012), knowledge concerning the development of this pool over periods exceeding 150 years is limited.

The main aim of this study was to assess how time on soil development since glacial retreat in a High Arctic glacier forefield impacts the soil $\mathrm{N}$ status and inputs of $\mathrm{N}$ by asymbiotic BNF along a 2000-year chronosequence.

\section{MATERIALS AND METHODS}

\section{Study site description}

The study was conducted in the forefield of the Midtre Lovénbreen alpine-type polythermal valley-glacier $\left(78^{\circ} 55^{\prime}\right.$ $\mathrm{N}, 12^{\circ} 10^{\prime} \mathrm{E}$ ) in northwest Spitsbergen, Svalbard, Norway, at an altitude of $\sim 50 \mathrm{~m}$ asl. Comprising an area of $\sim 5.5 \mathrm{~km}^{2}$, the glacier is $1 \mathrm{~km}$ wide at its equilibrium line $(\sim 365 \mathrm{~m}$ asl), exhibits a maximum thickness of $180 \mathrm{~m}$ and rises in elevation over $6 \mathrm{~km}$ from $50 \mathrm{~m}$ asl at the terminus to $600 \mathrm{~m}$ asl at the head (Rippin and others, 2003). The glacier has retreated by $\sim 1 \mathrm{~km}$ since reaching its Neoglacial maximum extent during the early 20th century, causing predominantly coarse-grained $(5-20 \mathrm{~cm})$ mineral soil of metamorphic origin to be exposed to atmospheric conditions (Rippin and others, 2003; Moreau and others, 2008). Vegetation cover in the forefield is sparse, where Saxifraga oppositifolia L., a vascular plant common to Arctic regions, was the most dominant species at each site along the chronosequence (for detailed information on vegetation cover see Hodkinson and others, 2003). The mean annual temperature for the years $1981-2010$ was $-5.2^{\circ} \mathrm{C}$. Mean annual precipitation for the same period was $427 \mathrm{~mm}$ (Førland and others, 2011). The average $1 \mathrm{~cm}$ soil temperature during the summer growing season (early July to late August) was $8^{\circ} \mathrm{C}$ (Bekku and others, 2003).

\section{Sample collection and preparation}

Surface soil (top $10 \mathrm{~cm}$ ) samples were collected along a proglacial post-incisive chronosequence between July and August 2013 (Bradley and others, 2016). The chronosequence comprised three parallel transects which were installed perpendicular to the leading edge of the glacier (Fig. 1). At each sampling site along the three transects, a $10 \mathrm{~m}$ traverse was installed parallel to the glacier's leading edge, where soil samples were extracted at $0 \mathrm{~m}, 5 \mathrm{~m}$ and $10 \mathrm{~m}$ across its length. Sampling sites occur at irregular intervals corresponding to the following soil ages (time since glacial retreat): 0 , 3, 5, 29 and 50 years $(n=9)$. In addition, one of the three transects included 113-year-old and $>1900$ (2000 hereinafter)-year-old sampling sites $(n=3)$. Soil ages had previously been determined by Bradley and others (2016) and Hodkinson and others (2003) using satellite imagery (Landsat TM 7), photographic records and carbon-14 dating techniques. As described by Bradley and

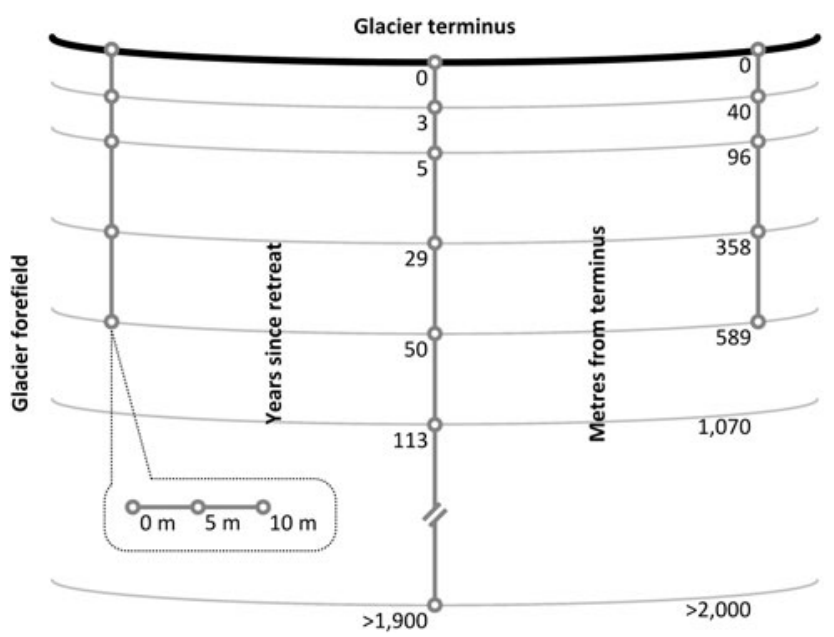

Fig. 1. Plan view of three transects which had been installed $\sim 127$ $\mathrm{m}$ apart between centres perpendicular to the terminus of a glacier to systematically sample the surface soil $(10 \mathrm{~cm})$ of a glacier forefield at irregular intervals corresponding to soil age (not to scale). Three soil samples were collected at 0-, 5- and 10-m intervals along a traverse parallel to the terminus at each sampling point $(n=9$ for 0 - to 50 year-old soils; $n=3$ for 113- to $>1900$-year-old soils).

others (2016), the fine earth fraction $(\leq 2000 \mu \mathrm{m})$ of the soil samples was separated from coarser material in the field, transferred to high-density polyethylene bags (Whirl-Pak ${ }^{\circledR}$; Lactun, Australia) and immediately frozen at $-20^{\circ} \mathrm{C}$. Representative aliquots of frozen sample were freeze-dried for elemental analysis, whereas aliquots for the determination soil texture, soil nutrient concentrations and nitrogenase activity were thawed in the dark at $4{ }^{\circ} \mathrm{C}$ prior to analysis.

\section{Soil texture}

A Malvern Mastersizer 3000 laser particle size analyser (Malvern Instruments Ltd., Worcestershire, UK) in the measurement range of $0.02 \mu \mathrm{m}$ to $2 \mathrm{~mm}$ was used to determine the particle-size distribution of the soil fine earth fraction, where samples were dispersed in a solution of sodium hexametaphosphate and sodium carbonate using Hydro EV pump accessory (Lamorski and others, 2014). Soil texture was subsequently defined according to the USDASCS (1982) classification scheme, and the percentage sand and clay content used to estimate water holding capacity (\%; Saxton and Rawls, 2006).

\section{Soil organic carbon and total nitrogen}

An elemental analyser (CHNS-O EA 1108 Elemental Analyzer; Carlo Erba, Milan, Italy) was used to determine the SOC and total $\mathrm{N}$ content in $\sim 100 \mathrm{mg}$ aliquots of soil after inorganic $\mathrm{C}$ had been removed by $\mathrm{HCl}$ vaporisation according to methods described by Hedges and Stern (1984). Prior to analysis, freeze-dried samples were embrittled using liquid $\mathrm{N}_{2}$, and ground to a flour using a pestle and mortar. The detection limits were $100 \mathrm{\mu g} \mathrm{g}^{-1}$ for both elements measured and the coefficient of variation for $\mathrm{C}$ and $\mathrm{N}$ according to six replicates of a standard reference material (SRM 338 40025, cert. 133317, $C=2.29 \%, N=0.21 \%$,) were $\pm 1.69 \%$ and $\pm 1.36 \%$, respectively. Soil organic matter was in turn estimated from SOC using a conversion factor of 2 (Pribyl, 2010). 


\section{Soil nutrient analyses}

Concentrations of exchangeable $\mathrm{NH}_{4}-\mathrm{N}$ and $\mathrm{NO}_{3}-\mathrm{N}$ were determined by $\mathrm{KCl}$ extraction where aliquots of $0.2 \mathrm{~g}$ were amended with $10 \mathrm{~mL}$ of $2 \mathrm{M} \mathrm{KCl}(1: 50 \mathrm{w} / \mathrm{v}$ soil:extractant), shaken for $30 \mathrm{~min}$ at $160 \mathrm{rpm}$, centrifuged for $5 \mathrm{~min}$ at $4500 \mathrm{rpm}$ and filtered to $0.45 \mu \mathrm{m}$ using Whatman WCN plain cellulose nitrate filtrate papers. Concentrations of $\mathrm{NH}_{4}-\mathrm{N}$ (QuikChem ${ }^{\circledR}$ Method 31-107-06-1-I) and $\mathrm{NO}_{3}-\mathrm{N}$ (QuikChem $^{\circledR}$ Method 31-107-04-1-K) within the resulting extracts were quantified colorimetrically using a flow injection analyser (Lachat QuikChem 8500 Series 2 FIA system, Loveland, CO, USA), where the coefficient of variation (six replicate standards) for $\mathrm{NH}_{4}-\mathrm{N}$ and $\mathrm{NO}_{3}-\mathrm{N}$ was $\pm 3.7 \%$ and $\pm 0.9 \%$, respectively, according to mid-range standards (calibration range: $0-0.5 \mathrm{mg} \mathrm{L}^{-1}$ ). The respective detection limits for $\mathrm{NH}_{4}-\mathrm{N}$ and $\mathrm{NO}_{3}-\mathrm{N}$ were $0.04 \mu \mathrm{g} \mathrm{g}^{-1}$ and $0.01 \mu \mathrm{g} \mathrm{g}{ }^{-1}$ for dry sediment. Bioavailable P (sum of loosely sorbed, and iron- and aluminium-bound P) was sequentially extracted from $0.2 \mathrm{~g}$ of soil using the SEDEX method (Ruttenberg, 1992; Ruttenberg and others, 2009) and analysed colorimetrically using a segmented flow analyser (SEAL AA3, Norderstedt, Germany). Detection limits for both loosely sorbed, and iron- and aluminium-bound $\mathrm{P}$ was $0.05 \mu \mathrm{g}$ $\mathrm{g}^{-1}$. The coefficient of variation (six replicate standards) for the same fractions were both $<0.5 \%$. Samples were blankcorrected when blank concentrations exceeded the detection limits. All results were reported on a dry weight basis, where percentage dry matter content (DMC) was determined gravimetrically using methods described by Rowell (1994).

\section{Biological nitrogen fixation}

Nitrogenase activity was assessed using the acetylene $\left(\mathrm{C}_{2} \mathrm{H}_{2}\right)$ reduction assay technique adapted from Telling and others (2011) as described by Turpin-Jelfs and others (2018). The number of samples per soil age was reduced from nine to three by homogenising the three samples obtained from the $10 \mathrm{~m}$ traverses at each sampling site along the transects $(n=3)$. Aliquots from each sample (equivalent to $7.5 \mathrm{~g}$ dry weight) were transferred to gas-tight $30 \mathrm{~mL}$ serum bottles and incubated $8 \pm 0.1^{\circ} \mathrm{C}$ (mean summer temperature) under $16 \mathrm{~W}$ florescent lamps (Sylvania, Garching, Germany) with emission spectra in the range $300-700 \mathrm{~nm}$ and irradiance equal to $0.2 \pm 0.005 \mathrm{~W} \mathrm{~m}^{-2}$. Following a 72 -h pre-incubation period, $10 \%$ of the headspace from each bottle was replaced with $100 \% \mathrm{C}_{2} \mathrm{H}_{2}$ gas, which had been produced by adding Milli-Q water to technical grade calcium carbide (Sigma, St. Louis, MO, USA). Serum bottles were sampled using a gas-tight syringe at 0-, 3-, 6-, 12-, 20- and 24-h intervals. At the time of sampling, $5 \mathrm{~mL}$ of air: $\mathrm{C}_{2} \mathrm{H}_{2}$ (9:1) was added to each serum bottle, mixed thoroughly by plunging the syringe six times and subsequently transferred to preevacuated $3.7 \mathrm{~mL}$ Exetainers (Labco, Lampeter, UK). A 1 $\mathrm{mL}$ aliquot of headspace from each Exetainer was then analysed using a Varian 3800 gas chromatograph (GC; Varian, Inc., Palo Alto, CA, USA), where ethylene $\left(\mathrm{C}_{2} \mathrm{H}_{4}\right)$ was separated from $\mathrm{C}_{2} \mathrm{H}_{2}$ using a $6^{\prime} \times 1 / 8^{\prime \prime}, 80 / 100$ mesh HayeSep T column at $85^{\circ} \mathrm{C}$ (He carrier gas). Daily standards of 100 ppm $\mathrm{C}_{2} \mathrm{H}_{4}$ (BOC, Guildford, UK) gave precisions of $<5 \%$. The precision for $100 \mathrm{ppm}$ standards that had been stored in $3.7 \mathrm{~mL}$ for a period of 1 month also gave precisions of $<5 \%$. Detection limits were $<0.01 \mathrm{nmol} \mathrm{C}_{2} \mathrm{H}_{4} \mathrm{~g}^{-1}$ for dry sediment. The $\mathrm{C}_{2} \mathrm{H}_{4}$ produced in $24 \mathrm{~h}$ was converted to $\mathrm{N}_{2}$ using the theoretical molar ratio of 3:1 $\left(B N F_{\text {day; }}\right.$ nmol $\mathrm{N}$ $\left.\mathrm{g}^{-1} \mathrm{~d}^{-1}\right)$. Potential annual rates asymbiotic BNF per unit area $\left(B N F_{\text {annual }} ; g \mathrm{~m}^{-2} \mathrm{a}^{-1}\right)$ were determined using Eqn (1):

$$
B N F_{\text {annual }}=B N F_{\text {day }} \times \text { depth }_{\text {soil }} \times \rho \times \text { time }
$$

where depth soil $_{\text {was }}$ the top $1 \mathrm{~cm}$ of the surface soil, $\rho$ was the reference bulk density which was calculated as a function of the soil clay, silt, sand and organic matter content (Keller and Håkansson, 2010), and time was the length of the summer melt season (60 days; Hodson and others, 2005). All sample measurements were blank-corrected using corresponding autoclaved soil samples $\left(126^{\circ} \mathrm{C}\right.$ for $\left.30 \mathrm{~min}\right)$. Controls for natural $\mathrm{C}_{2} \mathrm{H}_{4}$ production in the absence of $\mathrm{C}_{2} \mathrm{H}_{2}$ and $\mathrm{C}_{2} \mathrm{H}_{4}$ consumption were consistently below the limits of detection.

\section{Statistical analysis}

Statistical analysis of the data was performed using $\mathrm{R}$ version 3.5.0. The Kruskal-Wallis $H$ test (KW) was used to determine if significant differences occurred for data along the forefield chronosequence. When significance was indicated, Dunn's test (DT) of multiple comparisons was applied. Relationships between explanatory and response variables were explored using simple linear regression analysis, where residuals were inspected for evidence of nonnormality using the Shapiro-Wilk test. To reduce leverage by extreme predictors, data pertaining to the 2000-year-old soil samples were not included in regression models. For this study, the alpha level was set to 0.05. All errors reported in the text are one median absolute deviation about the median (Crawley, 2005).

\section{RESULTS}

\section{Soil texture}

The 0- to 50-year-old soils were silt loams, whereas the 113to 2000-year-old soils were clays (Fig. 2). Soil clay content was significantly influenced by soil age (DT, $p<0.001$ ), where clay particles decrease from $6 \pm 1 \%$ to $4 \pm 1 \%$ between the 0 - and 50 -year-old soils (DT, $p<0.001$ ). The soil clay content then increases dramatically to $50 \pm 17 \%$ and $80 \pm 3 \%$ in the 113- and 2000-year old soils, respectively. Soil silt and sand fractions do not differ between the 0 - and 50-year-old soils ( $p>0.05)$. However, the silt fraction decreases from $64 \pm 1 \%$ in the 50 -year-old soil to $\sim 12 \%$ in the 113- and 2000-year-old soils. Further, the soil sand content decreases sharply from $38 \pm 12 \%$ in the 113 -yearold soil to $10 \pm 1 \%$ in the 2000 -year-old soil.

\section{Distribution and speciation of nitrogen}

The total $\mathrm{N}$ content of the forefield soils was strongly influenced by soil age $\left(R^{2}=0.92, p<0.01\right)$. Between the 0 - and 50-year-old soils, concentrations of total $\mathrm{N}$ increase from 84 $\pm 12 \mu \mathrm{gg}^{-1}$ to $215 \pm 47 \mu \mathrm{gg}^{-1}$ (Fig. 3a). Specifically, the total $\mathrm{N}$ content of the 0 -year-old soil is lower in comparison with the 3- to 50-year-old soils (DT, $p<0.05$ ), and the total $\mathrm{N}$ content of the 3 -year-old soil is lower relative to that of the 29- and 50-year-old soils (DT, $p<0.05$ ). In addition, concentrations of total $\mathrm{N}$ subsequently rise to $606 \pm 70 \mu \mathrm{g} \mathrm{g}^{-1}$ in the 113 -year-old soil and to $4399 \pm 498 \mu \mathrm{g} \mathrm{g}^{-1}$ in the 2000 year-old soil. 


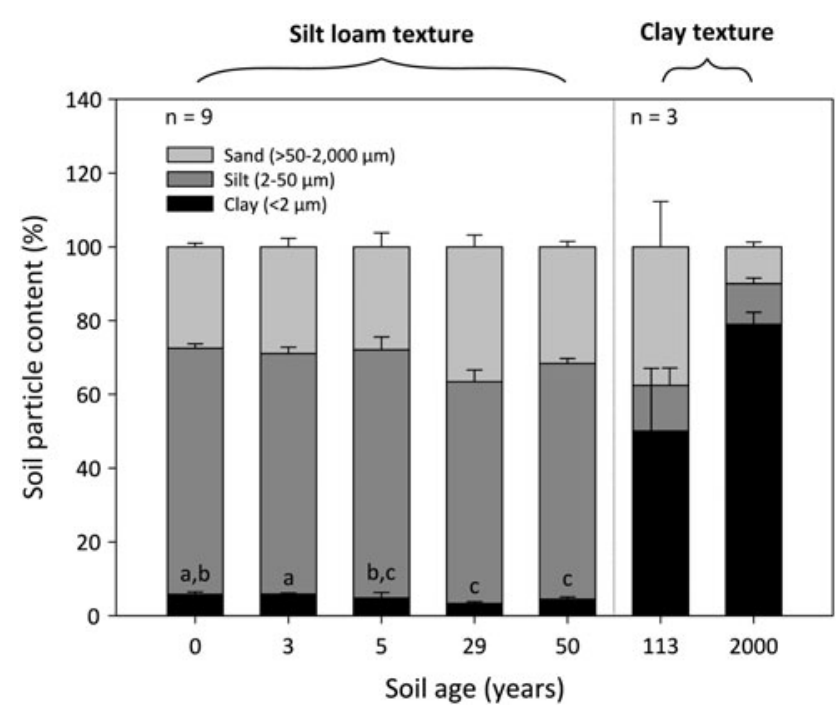

Fig. 2. Median percentage clay, silt and sand content of surface soil (top $10 \mathrm{~cm}$ ) from a glacier forefield in Svalbard, Norway. Groups denoted with different letters indicate significant differences at $p<0.05$ (Dunn's test). Error bars represent median absolute deviation about the median. Soil textural classes are displayed in bold and were defined according to the USDA-SCS (1982) classification scheme.

The relative contribution of inorganic $\mathrm{N}$ to total $\mathrm{N}$ decreases from $4 \%$ in the 0 -year-old soil to $1 \%$ in the 2000 -year-old soil. Inorganic $\mathrm{N}$ within the 0 - to 50 -year-old soils chiefly comprises $\mathrm{NO}_{3}-\mathrm{N}$, where median concentrations of $\mathrm{NH}_{4}-\mathrm{N}$ are below the limits of detection (Figs $3 \mathrm{~b}$ and c). Further, $\mathrm{NO}_{3}-\mathrm{N}$ levels are not influenced by soil age and do not differ between the 0 - and 50-year-old soils ( $\mathrm{KW}, p>0.05$ ). Conversely, the inorganic $\mathrm{N}$ content of the 113-year-old soil increases by $55 \%$ above that of the 50 -year-old soil due to a linear rise in concentrations of $\mathrm{NH}_{4}-\mathrm{N}$ with soil age $\left(R^{2}=0.80, p<0.05\right)$. Subsequent gains of both $\mathrm{NH}_{4}-\mathrm{N}$ and $\mathrm{NO}_{3}-\mathrm{N}$ within the 2000-year-old soil serve to increase inorganic $\mathrm{N}$ by $586 \%$ above the concentrations observed in the 113 -year-old soil, of which only $21 \%$ is in the form of $\mathrm{NO}_{3}-\mathrm{N}$.

\section{Nutrient ratios}

Ratios of SOC:total $N(C: N)$ are not significantly influenced by soil age $\left(R^{2}=0.11, p>0.05\right)$ and remain constant along the encroachment gradient where the median $\mathrm{C}: \mathrm{N}$ ratios in the
0 - and 113-year-old soils are $8 \pm 3$ and $7 \pm 2$, respectively (Fig. 4a). However, inorganic $\mathrm{N}$ :bioavailable $\mathrm{P}(\mathrm{N}: \mathrm{P})$ ratios increase linearly with soil age $\left(R^{2}=0.77, p<0.05\right)$ from 0.3 \pm 0.1 in the 0 -year-old soil to $0.6 \pm 0.1$ in the 113 -year-old soil (Fig. 4b). Further, the N:P ratios of the 0 - to 113 -year-old soils generally exhibited lower variability than corresponding $\mathrm{C}: \mathrm{N}$ ratios.

\section{Acetylene reduction assay}

Potential annual rates of asymbiotic BNF decrease with soil age from $0.16 \pm 0.04 \mathrm{~g} \mathrm{~N} \mathrm{~m}^{-2} \mathrm{a}^{-1}$ in the 0 -year-old soil to below detection limits in the 5 -year-old soil. Potential BNF rates were derived from rates of $\mathrm{C}_{2} \mathrm{H}_{4}$ production, which were linear over the 24-h period for both the $0-\left(R^{2}=0.95\right.$, $p<0.01)$ and 3-year-old $\left(R^{2}=0.67, p<0.05\right)$ soils (Figs $5 \mathrm{a}-\mathrm{C}$ ). $\mathrm{C}_{2} \mathrm{H}_{2}$ reduction assays of the 29-, 50-, 113and 2000-year-old soils were not performed as $\mathrm{C}_{2} \mathrm{H}_{4}$ production during the preliminary incubations of these samples, as well as the 5-year-old samples, were below the limits of detection (data not shown here). The preliminary incubations, which were also performed in triplicate, adhered to the methods previously outlined (i.e., incubated in the light at $8^{\circ} \mathrm{C}$ ), but were only sampled at 0 - and 24 -h intervals after the 72-h pre-incubation period. These preliminary incubations were also corrected for background $\mathrm{C}_{2} \mathrm{H}_{4}$ levels via blanks containing autoclaved soil samples in the presence of $\mathrm{C}_{2} \mathrm{H}_{2}$ and assessed for natural $\mathrm{C}_{2} \mathrm{H}_{4}$ production and consumption.

\section{DISCUSSION}

Our study revealed that time on soil development since glacial retreat strongly influences the distribution and speciation of $\mathrm{N}$ in the surface soil of the Midtre Lovénbreen glacier forefield. Further, we determined that $\mathrm{N}$ inputs by asymbiotic diazotrophs represent an important source of bioavailable $\mathrm{N}$ to this ecosystem. Here we discuss specifically how the soil $\mathrm{N}$ pool, as well as potential rates of asymbiotic BNF, vary along a 2000-year chronosequence of soil development in a High Arctic glacier forefield.

\section{Distribution and speciation of soil nitrogen}

Our findings are in agreement with a comprehensive review carried out by Bradley and others (2014) which showed the
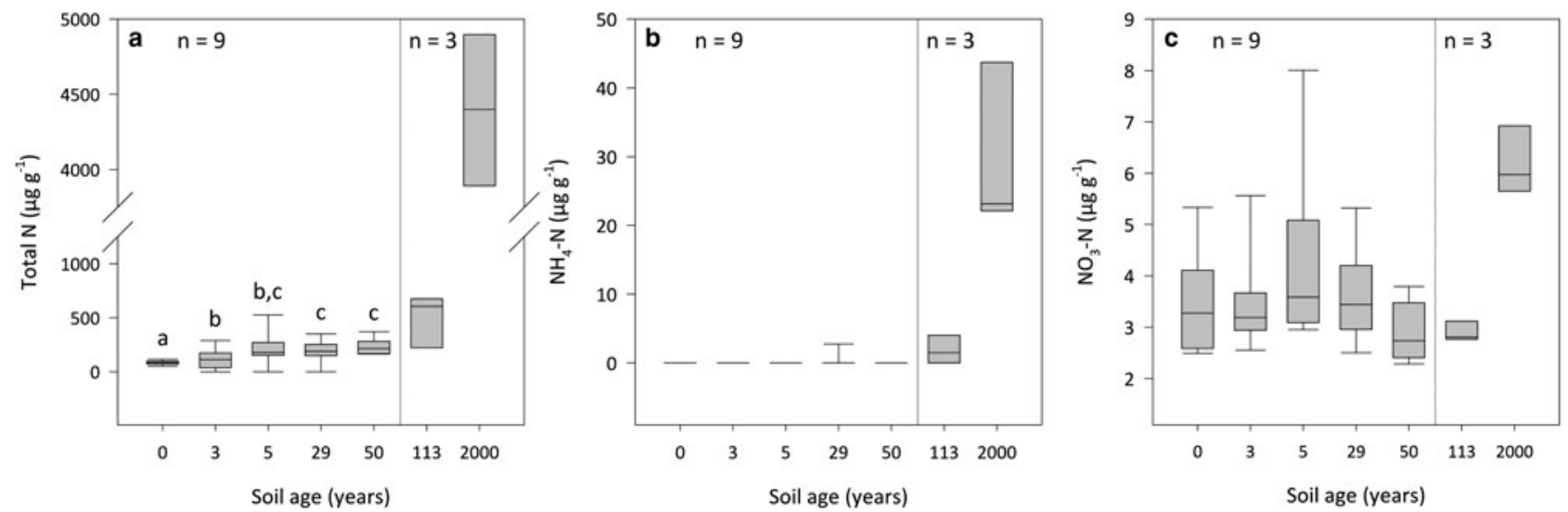

Fig. 3. Total $\mathrm{N}(\mathrm{a}), \mathrm{NH}_{4}-\mathrm{N}$ (b) and $\mathrm{NO}_{3}-\mathrm{N}$ (c) concentrations for surface soil (top $10 \mathrm{~cm}$ ) by dry weight for a glacier forefield chronosequence in Svalbard, Norway. Boxes denoted with different letters indicate significant differences at $p<0.05$ (Dunn's test). Results reported on dry matter basis. 

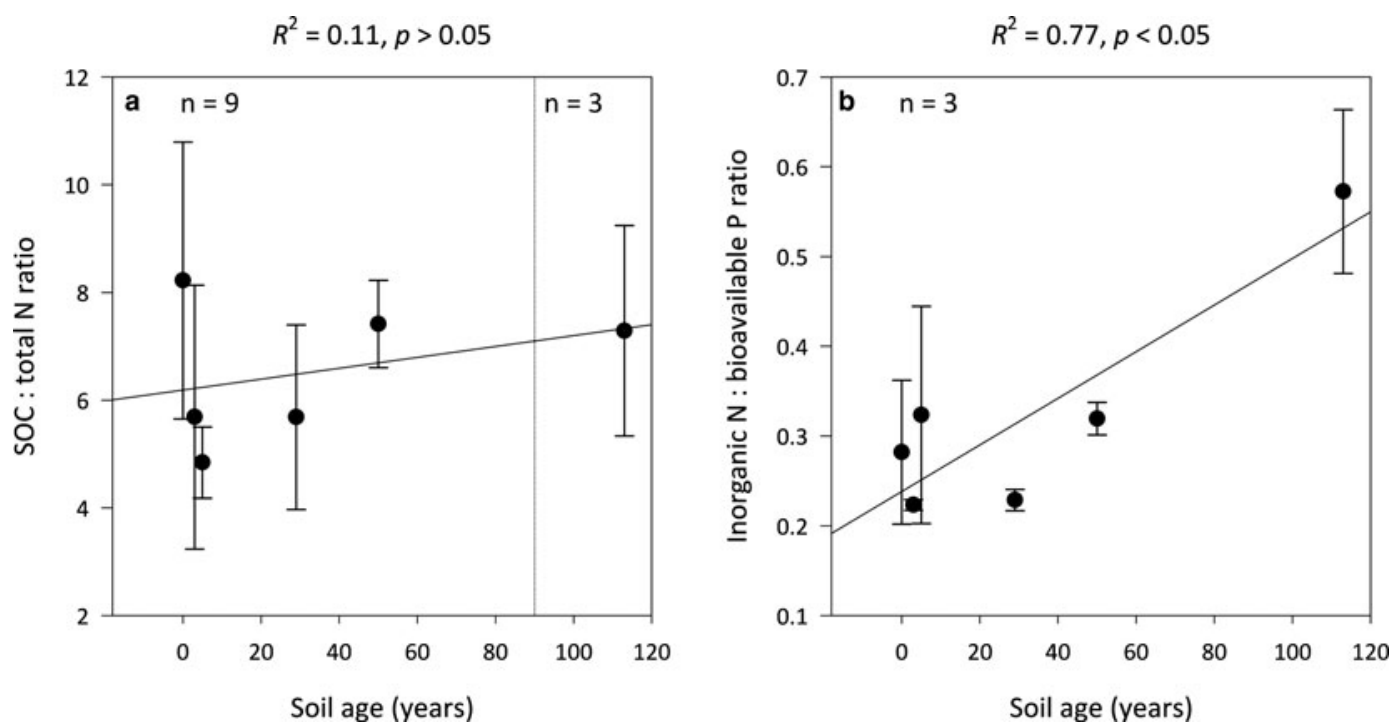

Fig. 4. Median SOC:total $N(a)$ and inorganic $N$ :bioavailable $P(b)$ ratios for surface soil $($ top $10 \mathrm{~cm}$ ) for a glacier forefield chronosequence in Svalbard, Norway. Error bars represent median absolute deviation about the median. Results reported on dry matter basis.

total $\mathrm{N}$ content of glacier forefield soils typically increase with soil age (Fig. 3a). We observed that total $\mathrm{N}$ initially increases by $\sim 100 \mathrm{\mu g} \mathrm{g}^{-1}$ above $84 \pm 12 \mu \mathrm{g} \mathrm{g}^{-1}$ between the 0 - and 50-year-old soils, which are dominated by a silt loam texture (Fig. 2). The accumulation of total $\mathrm{N}$ subsequently accelerates with the increased colonisation of the surface by plants at sites which have been ice-free for 113 $\left(606 \pm 70 \mu \mathrm{g} \mathrm{g}^{-1}\right)$ and $2000 \quad\left(4399 \pm 498 \mu \mathrm{g} \mathrm{g}^{-1}\right)$ years (Hodkinson and others, 2003), and exhibit a clay texture. Greater concentrations of total $\mathrm{N}$ in vegetated soils are to be expected as plants have been shown to increase the soil $\mathrm{N}$ pool through inputs of nutrient-rich litter and exudates, as well symbiotically-fixed $\mathrm{N}$ resulting from associations with rhizobia (Duc and others, 2009). In addition, the soil clay content, which increases substantially between the silt loam- and clay-textured soils is important for stabilising soil organic matter (Egli and others, 2010), where the percentage of total $\mathrm{N}$ which is organically bound (total $\mathrm{N}$ minus the sum of $\mathrm{NH}_{4}-\mathrm{N}$ and $\mathrm{NO}_{3}-\mathrm{N}$ ) ranges from $96 \pm 1 \%$ in the 0 -year-old soil to $99 \pm 0.1 \%$ in the 2000-year-old soil (Figs 3a-c). Interestingly, increases in total $\mathrm{N}$ between the 0 - and 50year-old soils did not share a clear relationship with the soil clay content. This discovery is corroborated by a study of the Damma glacier forefield, Switzerland, by Dümig and others (2011) which also failed to identify a clear trend in the soil clay content with age, and demonstrated that the accumulation of soil organic matter did not share a linear relationship with soil texture.

In contrast to model simulations by Bradley and others (2016) which showed that inorganic $\mathrm{N}$ accumulates at a relatively constant rate within Midtre Lovénbreen forefield, we observed that concentrations of inorganic $\mathrm{N}$ remain largely stable at 3-4 $\mathrm{\mu g} \mathrm{g}^{-1}$ between the 0 - and 113-year-old soils (Figs $3 \mathrm{~b}$ and c). As $\mathrm{NO}_{3}-\mathrm{N}$ was found to constitute $100 \%$ of inorganic $\mathrm{N}$ in the silt loam-textured soils (ice-free for $0-50$ years), it may be reasoned that inputs of $\mathrm{NH}_{4}-\mathrm{N}$ are rapidly immobilised by the soil microbial biomass (Bradley and others, 2016). Indeed, a study of the Loch Vale Watershed in the Colorado Rocky Mountains, USA, by Baron and others (1995) showed that $\mathrm{NH}_{4}-\mathrm{N}$, which comprised $~ 50 \%$ of received inorganic $\mathrm{N}$ deposition, was incorporated directly into biomass or oxidised to $\mathrm{NO}_{3}-\mathrm{N}$ in soil, as well as snow pack and surface waters. Conversely, the increase in $\mathrm{NH}_{4}-\mathrm{N}$ in the 113- and 2000-year-old soils (Fig. 3b) suggests
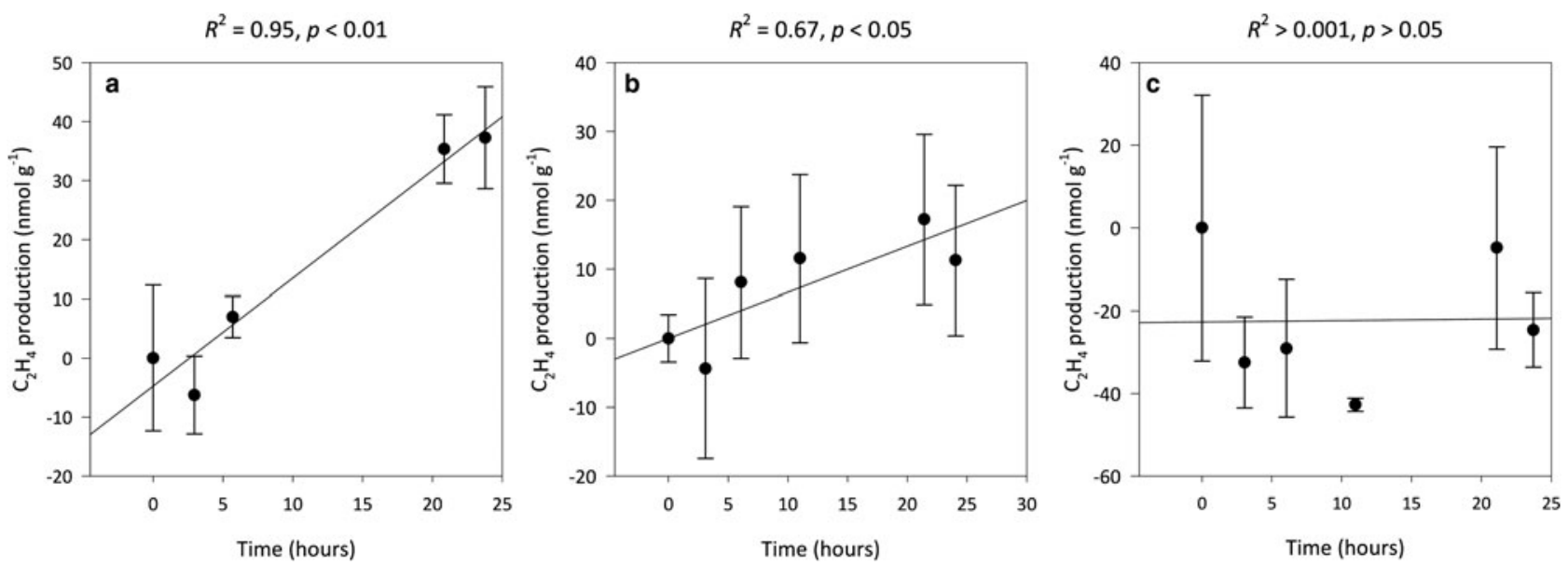

Fig. 5. Median ethylene $\left(\mathrm{C}_{2} \mathrm{H}_{4}\right)$ production for 0- (a), 3- (b) and 5-year-old (c) soils from a glacier forefield in Svalbard, Norway ( $\left.n=3\right)$. Error bars represent median absolute deviation about the median. Results reported on dry matter basis. 
that mineralisation processes are sufficient to facilitate the accumulation of inorganic $\mathrm{N}$ in the clay-textured soils (Bradley and others, 2016). This is supported by studies of the Damma glacier (Switzerland; Töwe and others, 2010), and Ödenwinkelkees and Rotmoosferner glaciers (Austria; Tscherko and others, 2003) which showed that functional genes (chiA and aprA) and rates of $\mathrm{N}$ mineralisation increase with soil age, respectively. Despite soil $\mathrm{C}: \mathrm{N}$ ratios remaining constant across the chronosequence (Fig. 4a), the lack of inorganic $\mathrm{N}$ accumulation in the silt loam-textured soils is indicative $N$ limitation (Schimel and others, 2004). Consequently, the capacity for BNF should represent a selective advantage in the silt loam-textured soils.

\section{Inputs of asymbiotically-fixed nitrogen}

We found that linear rates of asymbiotic $\mathrm{BNF}\left(\mathrm{C}_{2} \mathrm{H}_{4}\right.$ production) only occur at levels above the limits of detection in the 0 - and 3-year-old soils from the Midtre Lovénbreen glacier forefield (Figs $5 \mathrm{a}-\mathrm{C}$ ). These rates of BNF measured in the forefield soils are more than five and ten times greater than those for marine terrace soils $\sim 10 \mathrm{~km}$ from the study site (Solheim and others, 1996) and the Midtre Lovénbreen glacier (Telling and others, 2011), respectively, but are in the range reported for soils in polar desert and alpine tundra ecosystems by Cleveland and others (1999), as well as cyanobacteria-bryophyte symbioses in Svalbard (Solheim and others, 1996). Further, if, to facilitate comparisons with Telling and others (2011), the 0- and 3-year-old soils were each conservatively assumed to represent $1 \%$ of the Midtre Lovénbreen catchment area, they would collectively provide the system with $\sim 2 \mathrm{~kg} \mathrm{~N} \mathrm{~km}^{-2} \mathrm{a}^{-1}$. This is two orders of magnitude greater than $\mathrm{N}$ inputs by the cryoconite microbial community on the glacier (Telling and others, 2011), and equivalent to 5\% of annual $\mathrm{N}$ inputs to the catchment by rain and snow during the 1999/2000 melt season (Hodson and others, 2005). Thus, despite constituting an overall lower input of $\mathrm{N}$ to the system than rain and snow, our findings suggest the microbially mediated fixation of $\mathrm{N}$ by asymbiotic diazotrophs may provide an important source of assimilatory $\mathrm{N}$ during the initial stages of soil development in the forefield system. This is supported by studies for the Anvers Island (Antarctica; Strauss and others, 2012), Damma (Switzerland; Töwe and others, 2010), Puca (Peru; Schmidt and others, 2008) and Mendenhall (AK, USA; Sattin and others, 2009; Knelman and others, 2012) glaciers which showed that asymbiotic BNF promoted the accumulation of $\mathrm{N}$ and successional changes within the microbial community of recently deglaciated soils. However, in contrast to our findings, these studies have shown that nitrogenase activity typically increased in soils between 0 and 10 years of age (Schmidt and others, 2008; Sattin and others, 2009; Strauss and others, 2012).

Nitrogenase activity declined with soil age in the Midtre Lovénbreen forefield (Figs $5 \mathrm{a}-\mathrm{C}$ ). As $\mathrm{N}: \mathrm{P}$ ratios increase linearly with time on soil development (Fig. 4b), these findings support the theory that nitrogenase activity will down-regulate as the availability of $\mathrm{N}$ increases relative to $\mathrm{P}$ (Smith, 1992), and are substantiated by Telling and others (2011) who demonstrated that potential rates of asymbiotic BNF by the cryoconite microbial community on the Midtre Lovénbreen glacier, as well as the neighbouring Austre Brøggerbreen and Vestre Brøggerbreen glaciers, decline with increases in the availability of N. Further, a study by
Nash and others (2018) in the same site as ours showed the abundance of the nifH gene, an important marker of diazotrophs, increase as concentrations of total $\mathrm{N}$ decline below $1000 \mathrm{\mu g} \mathrm{g}^{-1}$. In contrast, Brankatschk and others (2011) found the nifH gene abundance of soils from the Damma glacier forefield in Göscheneralp, Switzerland, increased with gains in total $\mathrm{N}$ between soils which had been ice-free 10 and 50 years. However, this increase was attributed to a greater competition for $\mathrm{N}$ as plant cover rose from $<10 \%$ to $>70 \%$ with the number of years since exposure. As gains in soil $\mathrm{N}$ in this study were limited to the organic phase in the silt loam-textured soils, it may be inferred that increases in organic $\mathrm{N}$ with soil age are adequate to sustain growth within the microbial biomass.

We caution treating the potential BNF rates presented here as absolutes. Uniform incubation parameters were used to achieve linear rates of $\mathrm{C}_{2} \mathrm{H}_{2}$ reduction over a 24-h period, where parameters were chosen to reflect mean summer growth/melt season conditions. As the soil microbial community in the Midtre Lovénbreen forefield is dominated by autotrophic organisms (Hodkinson and others, 2003; Bradley and others, 2017; Nash and others, 2018), it was reasoned that nitrogenase activity, which is positively correlated with the soil moisture content (Chapin and others, 1991), would be restricted to a period when water is available to the biota (Logan, 1968). However, despite low temporal variability in the soil $\mathrm{N}$ pool during the short summer season in Svalbard (Bardgett and others, 2007), it may be argued that $\mathrm{N}$ inputs released to the soil solution through snowmelt and rainfall may influence potential rates of asymbiotic BNF. Indeed, Telling and others (2011) demonstrated that $\mathrm{N}$ fixation by the cryoconite microbial community on the Midtre Lovénbreen glacier was constrained by inputs of $\mathrm{N}$ from snowmelt. For this reason, we consider it prudent to present potential rates of BNF as a range based on a conservative 20 - and maximum 60-day summer period equal to $0.7-2 \mathrm{~kg} \mathrm{~N} \mathrm{~km}^{-2} \mathrm{a}^{-1}$. The lower extremum of this range is similar to potential rates of BNF by cryoconite on the sediment-covered marginal zone on Leverett Glacier in Greenland $\left(0.8 \mathrm{~kg} \mathrm{~N} \mathrm{~km}^{-2} \mathrm{a}^{-1}\right)$ which was determined to be important to the colonisation of moraine-derived sediments in that area (Telling and others, 2012).

In addition to time, other factors may have introduced uncertainty into the BNF data presented here. As the depth to which autotrophs can colonise is limited by the availability of photosynthetically active radiation (Jeffery and others, 2009), our estimates of fixation per unit area were restricted to the top $1 \mathrm{~cm}$ of the surface soil, as light penetration beyond this depth in bare and coarse soils would not be significant (Tester and Morris, 1987). Such an assumption may be insufficient to adequately characterise contributions of $\mathrm{N}$ fixation by heterotrophic diazotrophs, which may occur throughout the surface soil matrix and achieve comparable rates of BNF to their autotrophic counterparts (Strauss and others, 2012). Further, as photosynthesis, which shares a positive relationship with nitrogenase activity, increases with higher irradiance (Rabouille and others, 2006), it is possible that potential rates of BNF were limited by the incubation light source in the laboratory experiments being three orders of magnitude lower than the global average of $198 \mathrm{~W} \mathrm{~m}^{-2}$ (Le Treut and others, 2007). Lastly, as $\mathrm{C}_{2} \mathrm{H}_{4}: \mathrm{N}_{2}$ conversion factors for naturally-occurring cyanobacteria in soil range from 1.9 to 6.1 , it is recommended that conversions of $\mathrm{C}_{2} \mathrm{H}_{4}$ to $\mathrm{N}$ are calibrated using a ${ }^{15} \mathrm{~N}$ dilution (Belnap, 
2001). As conversions from $\mathrm{C}_{2} \mathrm{H}_{4}$ to $\mathrm{N}$ were not calibrated in this study, it is possible that we may have over- or underestimated potential rates of BNF in this system. Nevertheless, the data serves to illustrate that asymbiotic BNF is an important $N$ input pathway to the Midtre Lovénbreen glacier forefield which declines with time on soil development (i.e., with the accumulation of $\mathrm{N}$ ).

\section{CONCLUSIONS}

Over the past century, glaciers in Arctic regions have undergone significant retreat with rapid changes in climate, exposing new soil-forming substrates to atmospheric conditions. Using a space-for-time substitution approach, we showed that the soil $\mathrm{N}$ pool, which is essential to terrestrial primary production, increases with time since exposure in the forefield of a High Arctic glacier. However, the extent to which soil $\mathrm{N}$ increases with time is influenced by soil texture, where $\mathrm{N}$ accumulates more rapidly in clay-textured (113 and 2000-years-old) than silt loam-textured soils (0-50years-old). Further, in contrast to the clay-textured soils, we observed that gains in soil $\mathrm{N}$ were limited to the organic phase in the silt loam-textured soils. This suggests that inputs of inorganic $\mathrm{N}$ to the silt loam-textured soils are immobilised by the microbial biomass due to $\mathrm{N}$-limiting conditions. While $\mathrm{N}$ limitation should promote BNF, asymbiotic nitrogenase activity was only detectable in the 0 - and 3-year-old soils, where potential annual rates $\mathrm{N}$ fixation decline with increases in soil N. Nevertheless, we demonstrated that inputs of $\mathrm{N}$ by asymbiotic diazotrophs may represent an important source of assimilatory $\mathrm{N}$ during the initial stages of soil development in this glacier forefield. As glacier coverage is projected to decrease with continued climate warming, this study has implications for understanding how ice-free ecosystems develop and become productive over time.

\section{ACKNOWLEDGEMENTS}

The research was supported by a University of Bristol Graduate Teaching Studentship to TTJ for laboratory work and a NERC grant NE/J02399X/1 to AMA for fieldwork expenses. We are grateful for the use of the NERC facilities in Ny-Ålesund during field campaigns, and to Katherine Wright and James Bradley for their assistance with field sampling. In addition, we thank Francine Turpin for assisting with the analysis of samples during her work experience placement at the University of Bristol.

\section{DATA AVAILABILITY}

All data presented here is available at the following DOI: https://doi.org/10.5523/bris.5itwup6puf972p0tw4s77h9os.

\section{AUTHOR CONTRIBUTIONS}

TTJ led the design of the study, assisted by KM and AMA. All laboratory work, excluding $\mathrm{P}$ analyses, was performed by TTJ with assistance from JMW. P analyses were conducted by JJB and LGB. TTJ wrote the manuscript with contributions from $\mathrm{KM}$ and $\mathrm{AMA}$.

\section{COMPETING INTERESTS}

The authors declare that they have no conflict of interest.

\section{REFERENCES}

Bardgett RD and others (2007) Heterotrophic microbial communities use ancient carbon following glacial retreat. Biol. Lett., 3(5), 487

Baron JS, Allstott EJ and Newkirk BK (1995) Analysis of long-term sulfate and nitrate budgets in a Rocky Mountain basin. In Tonnessen KA, Williams MW and Tranter $M$ eds. Biogeochemistry of seasonally-snow-covered catchments. IASH Publ. No. 228, IASH Press, Oxfordshire

Bekku YS, Nakatsubo T, Kume A, Adachi M and Koizumi H (2003) Effect of warming on the temperature dependence of soil respiration rate in Arctic, temperate and tropical soils. Appl. Soil Ecol., 22(3), 205-210 (doi: http://dx.doi.org/10.1016/S0929-1393(02) 00158-0)

Belnap J (2001) Factors influencing nitrogen fixation and nitrogen release in biological soil crusts. In belnap J and Lange $\mathrm{O}$ eds. Biological soil crusts: structure, function, and management. Ecological Studies. Vol. 150. Springer, Berlin, DE, pp. 241-261

Bradley JA, Singarayer JS and Anesio AM (2014) Microbial community dynamics in the forefield of glaciers. Proc. R. Soc. B: Biol. Sci., 281(1795), (doi: 10.1098/rspb.2014.0882)

Bradley JA and others (2016) Microbial dynamics in a high Arctic glacier forefield: a combined field, laboratory, and modelling approach. Biogeosciences, 13, 5677-5696 (doi: https://doi.org/ 10.5194/bg-13-5677-2016)

Bradley JA, Anesio AM and Arndt S (2017) Microbial and biogeochemical dynamics in glacier forefields are sensitive to centuryscale climate and anthropogenic change. Front. Earth Sci., 5 (26), (doi: 10.3389/feart.2017.00026)

Brankatschk R, Towe S, Kleineidam K, Schloter M and Zeyer J (2011) Abundances and potential activities of nitrogen cycling microbial communities along a chronosequence of a glacier forefield. ISME J., 5(6), 1025-1037

Breen K and Lévesque E (2008) The influence of biological soil crusts on soil characteristics along a high Arctic glacier foreland, Nunavut, Canada. Arct. Antarct. Alp. Res., 40(2), 287-297 (doi: 10.2307/20181793)

Chapin DM, Bliss LC and Bledsoe LJ (1991) Environmental regulation of nitrogen fixation in a high Arctic lowland ecosystem. Can. J. Bot., 69(12), 2744-2755 (doi: 10.1139/b91-345)

Cleveland CC and others (1999) Global patterns of terrestrial biological nitrogen $\left(\mathrm{N}_{2}\right)$ fixation in natural ecosystems. Global Biogeochem. Cycles, 13(2), 623-645 (doi: 10.1029/1999GB900014)

Crawley MJ (2005) Statistics: an Introduction using R. John Wiley \& Sons Ltd, Chichester

Delgado-Baquerizo M, García-Palacios P, Milla R, Gallardo A and Maestre FT (2015) Soil characteristics determine soil carbon and nitrogen availability during leaf litter decomposition regardless of litter quality. Soil Biol. Biochem., 81, 134-142 (doi: https:// doi.org/10.1016/j.soilbio.2014.11.009)

Duc L, Noll M, Meier BE, Bürgmann H and Zeyer J (2009) High diversity of diazotrophs in the forefield of a receding alpine glacier. Microb. Ecol., 57(1), 179-190 (doi: 10.2307/ 40343441)

Dümig A, Smittenberg R and Kögel-Knabner I (2011) Concurrent evolution of organic and mineral components during initial soil development after retreat of the Damma glacier, Switzerland. Geoderma, 163(1), 83-94 (doi: https://doi.org/10.1016/j.geoderma.2011.04.006)

Egli M, Mavris C, Mirabella A and Giaccai D (2010) Soil organic matter formation along a chronosequence in the Morteratsch proglacial area (Upper Engadine, Switzerland). CATENA, 82(2), 61-69 (doi: https://doi.org/10.1016/j.catena.2010.05.001)

Ellis S and Mellor A (1995) Soil formation and environment. In Ellis S and Mellor A eds. Soils and environment. Routledge, London, 93-122

Førland EJ, Benestad R, Hanssen-Bauer I, Haugen JE and Skaugen TE (2011) Temperature and precipitation development at Svalbard 1900-2100. Adv. Meteorol., 2011, 893790 (doi: http://dx.doi. org/10.1155/2011/893790) 
Hassink J (1994) Effects of soil texture and grassland management on soil organic $\mathrm{C}$ and $\mathrm{N}$ and rates of $\mathrm{C}$ and $\mathrm{N}$ mineralization. Soil Biol. Biochem., 26(9), 1221-1231 (doi: https://doi.org/10.1016/ 0038-0717(94)90147-3)

Hedges JI and Stern JH (1984) Carbon and nitrogen determinations of carbonate-containing solids. Limnol. Oceanogr., 29(3), 657663 (doi: 10.4319/lo.1984.29.3.0657)

Hodkinson ID, Coulson SJ and Webb NR (2003) Community assembly along proglacial chronosequences in the high Arctic: vegetation and soil development in north-west Svalbard. J. Ecol., 91(4), 651-663 (doi: doi:10.1046/j.1365-2745.2003.00786.x)

Hodson AJ, Mumford PN, Kohler J and Wynn PM (2005) The high Arctic glacial ecosystem: new insights from nutrient budgets. Biogeochemistry, 72(2), 233-256 (doi: 10.1007/s10533-0040362-0)

Jeffery S, Harris JA, Rickson RJ and Ritz K (2009) The spectral quality of light influences the temporal development of the microbial phenotype at the arable soil surface. Soil Biol. Biochem., 41(3), 553-560 (doi: https://doi.org/10.1016/j.soilbio.2008.12.014)

Keller T and Håkansson I (2010) Estimation of reference bulk density from soil particle size distribution and soil organic matter content. Geoderma, 154(3), 398-406 (doi: https://doi.org/10. 1016/j.geoderma.2009.11.013)

Knelman JE and others (2012) Bacterial community structure and function change in association with colonizer plants during early primary succession in a glacier forefield. Soil Biol. Biochem., 46, 172-180 (doi: https://doi.org/10.1016/j.soilbio. 2011.12.001)

Lamorski K and 5 others (2014) Assessment of the usefulness of particle size distribution measured by laser diffraction for soil water retention modelling. J. Plant Nutr. Soil Sci., 177(5), 803-813 (doi: 10.1002/jpln.201300594)

Le Treut $\mathrm{H}$ and others (2007) Historical overview of climate change science. In Solomon S, Qin D, Manning M, Chen Z, Marquis M, Averyt KB, Tignor M and Miller HL eds. Climate change 2007: the physical science basis. Contribution of working group I to the fourth assessment report of the intergovernmental panel on climate change. Cambridge University Press, Cambridge, UK/New York, NY, 93-127

Logan F (1968) Causes, climates and distribution of deserts. In Brown GW , Jr. ed. Desert biology. Vol. I. Academic Press, Inc, London, 21-50

Menge DN and Hedin LO (2009) Nitrogen fixation in different biogeochemical niches along a 120 000-year chronosequence in New Zealand. Ecology, 90(8), 2190-2201

Moreau M, Mercier D, Laffly D and Roussel E (2008) Impacts of recent paraglacial dynamics on plant colonization: a case study on Midtre Lovénbreen foreland, Spitsbergen $\left(79^{\circ} \mathrm{N}\right)$. Geomorphology, 95(1), 48-60 (doi: https://doi.org/10.1016/j. geomorph.2006.07.031)

Nash MV and others (2018) Metagenomic insights into diazotrophic communities across Arctic glacier forefields. FEMS Microbiol. Ecol. (doi: 10.1093/femsec/fiy114)

Pribyl DW (2010) A critical review of the conventional SOC to SOM conversion factor. Geoderma, 156(3), 75-83 (doi: https://doi.org/ 10.1016/j.geoderma.2010.02.003)

Rabouille S, Staal M, Stal LJ and Soetaert K (2006) Modeling the dynamic regulation of nitrogen fixation in the cyanobacterium Trichodesmium sp. Appl. Environ. Microbiol., 72(5), 3217

Rippin D and others (2003) Changes in geometry and subglacial drainage of Midre Lovénbreen, Svalbard, determined from digital elevation models. Earth Surf. Processes Landforms, 28 (3), 273-298 (doi: 10.1002/esp.485)

Rowell DL (1994) Soil science: methods \& applications. Longman Group UK Ltd, London

Ruttenberg KC (1992) Development of a sequential extraction method for different forms of phosphorus in marine sediments. Limnol. Oceanogr., 37(7), 1460-1482 (doi: 10.4319/lo.1992.37.7.1460)
Ruttenberg KC and 5 others (2009) Improved, high-throughput approach for phosphorus speciation in natural sediments via the SEDEX sequential extraction method. Limnology and Oceanography: Methods, 7(5), 319-333 (doi: 10.4319/lom.2009.7.319)

Sattin SR and others (2009) Functional shifts in unvegetated, perhu$\mathrm{mid}$, recently-deglaciated soils do not correlate with shifts in soil bacterial community composition. J. Microbiol., 47(6), 673-681 (doi: 10.1007/s12275-009-0194-7)

Saxton KE and Rawls WJ (2006) Soil water characteristic estimates by texture and organic matter for hydrologic solutions. Soil Sci. Soc. Am. J., 70(5), 1569-1578 (doi: 10.2136/sssaj2005.0117)

Schimel JP, Bilbrough C and Welker JM (2004) Increased snow depth affects microbial activity and nitrogen mineralization in two Arctic tundra communities. Soil Biol. Biochem., 36(2), 217-227 (doi: https://doi.org/10.1016/j.soilbio.2003.09.008)

Schmidt SK and others (2008) The earliest stages of ecosystem succession in high-elevation (5000 metres above sea level), recently deglaciated soils. Proc. R. Soc. B: Biol. Sci., 275(1653), 2793

Smith V (1992) Effects of nitrogen: phosphorus supply ratios on nitrogen fixation in agricultural and pastoral ecosystems. Biogeochemistry, 18(1), 19-35 (doi: 10.1007/BF00000424)

Solheim B, Endal A and Vigstad H (1996) Nitrogen fixation in Arctic vegetation and soils from Svalbard, Norway. Polar Biol., 16(1), 35-40 (doi: 10.1007/BF02388733)

Stocker TF and others (2013) Technical summary. In Stocker TF, Qin D, Plattner G-K, Tignor M, Allen SK, Boschung J, Nauels A, Xia Y, Bex V and Midgley PM eds. Climate change 2013: the physical science basis. Contribution of working group I to the fifth assessment report of the intergovernmental panel on climate change. Cambridge University Press, Cambridge; New York, NY, 33-115

Strauss SL, Garcia-Pichel F and Day TA (2012) Soil microbial carbon and nitrogen transformations at a glacial foreland on Anvers Island, Antarctic Peninsula. Polar Biol., 35(10), 1459-1471 (doi: 10.1007/s00300-012-1184-5)

Telling J and others (2011) Nitrogen fixation on Arctic glaciers, Svalbard. J. Geophysical Res.: Biogeosci., 116(G3), G03039 (doi: 10.1029/2010JG001632)

Telling J and others (2012) Microbial nitrogen cycling on the Greenland ice sheet. Biogeosciences, 9(7), 2431-2442 (doi: 10.5194/bg-9-2431-2012)

Tester M and Morris C (1987) The penetration of light through soil. Plant, Cell Environ., 10, 281-286

Töwe $S$ and others (2010) Abundance of microbes involved in nitrogen transformation in the rhizosphere of Leucanthemopsis alpina (L.) Heywood grown in soils from different sites of the Damma Glacier forefield. Microb. Ecol., 60(4), 762-770 (doi: 10.1007/ s00248-010-9695-5)

Tscherko D, Rustemeier J, Richter A, Wanek W and Kandeler E (2003) Functional diversity of the soil microflora in primary succession across two glacier forelands in the Central Alps. Eur. J. Soil Sci., 54(4), 685-696 (doi: 10.1046/j.13510754.2003.0570.x)

Turpin-Jelfs T, Michaelides K, Biederman JA and Anesio AM (2018) Soil nitrogen response to shrub encroachment in a degrading semiarid grassland. Biogeosciences Discuss. (doi: 10.5194/bg2018-331)

USDA-SCS (1982) Procedures for collecting soil samples and methods of analysis for soil survey. U.S. Department of Agriculture, Washington, DC

Vitousek PM and Farrington H (1997) Nutrient limitation and soil development: experimental test of a biogeochemical theory. Biogeochemistry, 37(1), 63-75 (doi: 10.1023/A:1005757218475)

Vitousek PM and others (1997) Human alteration of the global nitrogen cycle: sources and consequences. Ecol. Appl., 7(3), 737-750 (doi: 10.2307/2269431)

Vitousek PM, Hattenschwiler S, Olander L and Allison S (2002) Nitrogen and nature. Ambio, 31(2), 97-101 